\title{
Reference evapotranspiration and crop water requirement of apple (Malus Pumila) in Kashmir Valley
}

\author{
LATIEF AHMAD ${ }^{1}$, SABAH PARVAZE ${ }^{1}$, SAQIB PARVAZE ${ }^{2}$ and RAIHANA HABIB KANTH ${ }^{1}$ \\ ${ }^{1}$ Agromet Field Unit-Srinagar, Division of Agronomy, ${ }^{2}$ Division of Agricultural Engineering \\ Sher-e-Kashmir University of Agricultural Sciences and Technology of Kashmir, Shalimar (J\&K) 190025 \\ Email:drlatief_skuastk@hotmail.com
}

\begin{abstract}
Reference evapotranspiration is a significant agrometeorological parameter used for estimation of crop water requirement and irrigation scheduling. The present study was undertaken to determine the reference evapotranspiration and crop water requirement for apple cultivation in the Kashmir valley. Reference evapotranspiration ( $\left.E T_{0}\right)$ was determined for seven major apple producing districts of Kashmir valley, viz. Srinagar, Budgam, Kupwara, Pulwama, Baramulla, Anantnag and Shopian. The average ET, for apples cultivation in Kashmir Valley was $912 \mathrm{~mm}$. The mean water requirement $\left(E T_{c}\right)$ was minimum during the initial stage being $69 \mathrm{~mm}$ and maximum during the mid-season stage being $668 \mathrm{~mm}$. The mean water requirement during the late-season stage was $175 \mathrm{~mm}$. The minimum annual ET, was observed at Baramulla $(846 \mathrm{~mm})$ and the maximum annual $\mathrm{ET}_{\mathrm{c}}$ at Srinagar $(953 \mathrm{~mm})$. Different stations showed variations in water requirement due to differences in altitude and local weather conditions.
\end{abstract}

Keywords: FAO Penman-Monteith method, reference evapotranspiration $\left(\mathrm{ET}_{0}\right)$, crop evapotranspiration $\left(\mathrm{ET}_{\mathrm{c}}\right)$, apple

Apple is a rosaceous fruit tree, that belongs to genus Malus. It is the most widely grown fruit tree in the world and is propagated in temperate regions of both northern and southern hemispheres due to its high economic value. In India, the major apple producing regions include Kashmir, Himachal Pradesh, Uttar Pradesh, Kumaon, Assam and Nilgiri Hills. Apple is the principal fruit crop of Jammu and Kashmir and accounts for nearly 48 per cent of total area under all temperate fruits grown in the state. The annual apple production in the state is 1.7 million metric tons. Average yield of commercially important apple cultivars per unit area is the highest in the country ranging between $10-12 \mathrm{tha}^{-1}$.

Weather conditions determine the water requirement of any crop (Ken et al., 2012). For efficient irrigation water management in apple orchards, quantification of evapotranspiration is very important. Accurate estimation of evapotranspiration by field measurements is very difficult and time-consuming. Reference evapotranspiration $\mathrm{ET}_{0}$ is estimated using empirical formulae based on meteorological data and is multiplied with crop coefficient to obtain crop evapotranspiration (Doorenbos and Pruitt 1977). The value of the crop coefficient depends on the type of crop, its stage of growth, canopy cover and crop density (Allen et al. 1998). In the present study, the reference evapotranspiration and the crop water requirement was estimated by means of
FAO-56 Penman-Monteith Method (Allen et al., 1998). The method has also been verified to be more suitable for Indian conditions than FAO-24 Penman method (Kashyap and Panda, 2001). The irrigation water use efficiency can be enhanced by the application of FAO-56 PM method and thus the distribution of water at different levels can be improved (Mehta and Pandey, 2015).

\section{MATERIALS AND METHODS}

The State of Jammu and Kashmir is located between $32^{\circ} 17^{\prime}$ and of $37^{\circ} 5$ North latitudes and $73^{\circ} 26^{\prime}$ and $80^{\circ} 30^{\prime}$ and $81^{\circ}$ East longitudes. The state has a very rugged topography and consists of nearly 66 per cent of the mountainous area of India. Kashmir Valley is a temperate zone having 10 districts. The elevation varies from $1500 \mathrm{~m}$ amsl in the plain areas to $4200 \mathrm{~m}$ in upper reaches which are mostly snow bound. The weather data for the period 1992 2016 was obtained from Agro-Meteorological Field Unit (AMFU) Shalimar and Regional Meteorological Centre, Srinagar for seven major apple producing districts of Kashmir valley, viz. Srinagar, Budgam, Kupwara, Pulwama, Baramulla, Anantnag and Shopian.

\section{FAO-56 Penman-Monteith method}

The Penman-Monteith method also known as FAO- 
Table 1: The monthly and annual values of $\mathrm{ET}_{0}(\mathrm{~mm})$ in seven districts of Kashmir Valley.

\begin{tabular}{lrrrrrrrr}
\hline Month & Srinagar & Budgam & Kupwara & Pulwama & Baramulla & Anantnag & Shopian & Average \\
\hline January & 24.8 & 21.7 & 21.7 & 21.7 & 21.7 & 21.7 & 24.8 & 22.6 \\
February & 36.0 & 36.0 & 33.0 & 33.0 & 30.0 & 30.0 & 36.0 & 33.4 \\
March & 62.0 & 62.0 & 62.0 & 58.9 & 52.7 & 55.8 & 62.0 & 59.3 \\
April & 87.0 & 84.0 & 87.0 & 84.0 & 75.0 & 78.0 & 87.0 & 83.1 \\
May & 114.7 & 114.7 & 114.7 & 111.6 & 102.3 & 105.4 & 111.6 & 110.7 \\
June & 132.0 & 129.0 & 129.0 & 126.0 & 117.0 & 117.0 & 126.0 & 125.1 \\
July & 130.2 & 130.2 & 130.2 & 127.1 & 117.8 & 117.8 & 127.1 & 125.8 \\
August & 117.8 & 114.7 & 117.8 & 111.6 & 105.4 & 105.4 & 111.6 & 112.0 \\
September & 93.0 & 90.0 & 93.0 & 90.0 & 84.0 & 84.0 & 90.0 & 89.1 \\
October & 62.0 & 62.0 & 62.0 & 62.0 & 55.8 & 58.9 & 62.0 & 60.7 \\
November & 36.0 & 33.0 & 33.0 & 33.0 & 30.0 & 33.0 & 36.0 & 33.4 \\
December & 21.7 & 21.7 & 21.7 & 21.7 & 21.7 & 21.7 & 24.8 & 22.1 \\
Annual Total & 917.2 & 899.0 & 905.1 & 880.6 & 813.4 & 828.7 & 898.9 & 877.6 \\
\hline
\end{tabular}

Table 2: Stage-wise and total water requirement of apple in

\begin{tabular}{lllll}
\multicolumn{4}{c}{ different districts of Kashmir Valley. } \\
\hline Station & $\begin{array}{l}\text { Initial } \\
\text { Stage }\end{array}$ & $\begin{array}{l}\text { Mid- } \\
\text { season } \\
\text { Stage }\end{array}$ & $\begin{array}{l}\text { Late } \\
\text { season } \\
\text { Stage }\end{array}$ & Total \\
\hline Srinagar & 74 & 698 & 181 & 953 \\
Ganderbal & 72 & 687 & 176 & 935 \\
Kupwara & 70 & 694 & 178 & 943 \\
Pulwama & 68 & 672 & 176 & 916 \\
Baramulla & 63 & 621 & 163 & 846 \\
Anantnag & 65 & 628 & 168 & 861 \\
Kulgam & 74 & 676 & 181 & 931 \\
\hline Mean & 69 & 668 & 175 & 912 \\
\hline
\end{tabular}

56 Penman-Monteith method is given as:

$E T_{0}=\frac{0.408 \Delta\left(R_{n}-G\right)+\gamma \frac{900}{T_{\text {mean }}+273} U_{2}\left(e_{s}-e_{a}\right)}{\Delta+\gamma\left(1+0.34 U_{2}\right)}$

Where,

$E T o=$ reference evapotranspiration $\left[\mathrm{mm} \mathrm{day}^{-1}\right]$,

$R_{n}=$ net radiation at the crop surface $\left[\mathrm{MJ} \mathrm{m}-2 \mathrm{day}^{-1}\right]$,

$G=$ soil heat flux density [MJ m-2 day ${ }^{-1}$,

Tmean $=$ mean daily air temperature at $2 \mathrm{~m}$ height $\left[{ }^{\circ} \mathrm{C}\right]$,

$U z=$ wind speed at $2 \mathrm{~m}$ height $\left[\mathrm{m} \mathrm{s}^{-1}\right]$,

$e s=$ saturation vapor pressure $[\mathrm{kPa}]$,

$e a=$ actual vapor pressure $[\mathrm{kPa}]$, $e s-e a=$ saturation vapor pressure deficit $[\mathrm{kPa}]$,

$\Delta=$ slope vapor pressure curve $\left[\mathrm{kPa}^{\circ} \mathrm{C}^{-1}\right]$,

$\gamma=$ psychrometric constant $\left[\mathrm{kPa}^{\circ} \mathrm{C}^{-1}\right]$.

\section{Crop coefficient $\left(K_{c}\right)$}

The crop coefficient curve has three important stages i.e. initial stage $\left(\mathrm{K}_{\mathrm{c} \text { ini }}\right)$, mid-season $\left(\mathrm{K}_{\mathrm{c} \text { mid }}\right)$ and end stage $\left(\mathrm{K}_{\mathrm{c} \text { end }}\right)$ respectively. The crop coefficient values used for the study were the FAO recommended values for the apple crop. The $\mathrm{K}_{\mathrm{cini}}$ value for apple crop was taken as 0.6 . The $\mathrm{K}_{\mathrm{c} \text { mid }}$ was 1.2 and the value of $\mathrm{K}_{\mathrm{c} \text { end }}$ was taken 0.85 .

\section{Crop water requirement (ET $\left.T_{c}\right)$}

The crop water requirement was computed from reference evapotranspiration as per Doorenbos and Pruitt(1977):

$E T_{c}=K_{c} X E T_{0}$

Where,

$E T_{c}=$ crop evaptranspiratin/crop water requirement $(\mathrm{mm}$ day $\left.^{-1}\right), E T_{0}=$ reference evapotranspiration $(\mathrm{mm}$ day $^{-1}$ ), and $K_{c}=$ crop coefficient.

The evapotranspiration was calculated on daily basis and then summed for different stages of growth and total water requirement of the apple crop.

\section{RESULTS AND DISCUSSIONS}

The monthly reference evapotranspiration $\left(\mathrm{ET}_{0}\right)$ in seven districts of Kashmir Valley presented in Table 1 shows 


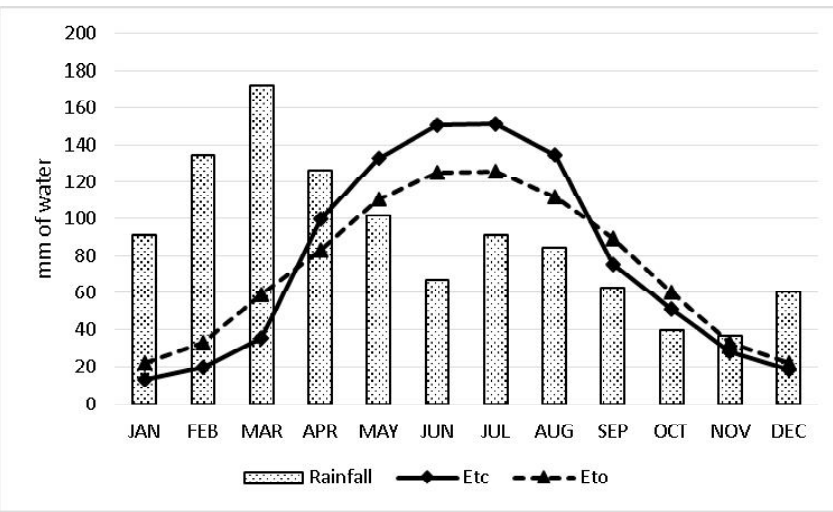

Fig. 1: Monthly variation of ET0 and ETc for Apple in Kashmir Valley

that $\mathrm{ET}_{0}$ was minimum during December and January $(21$ to $25 \mathrm{~mm}$ ) and maximum during June and July (117 to $173 \mathrm{~mm}$ ) across the stations. The annual $\mathrm{ET}_{0}$ was maximum (917.2 $\mathrm{mm})$ at Srinagar and minimum $(813.4 \mathrm{~mm})$ at Baramulla with mean of $877.6 \mathrm{~mm}$ in Kashmir Valley.

The water required by the apple crop during initial, mid and late season of growth was minimum during the initial stage and maximum during mid-season stage. The water requirement was minimum in Baramulla district for all the stages with a total of $846 \mathrm{~mm}$, while it was maximum in Srinagar district having a value of $953 \mathrm{~mm}$ (Table 2) with mean value of $912 \mathrm{~mm}$ for Kashmir Valley. The variation in water requirement in various districts is due to differences in altitude which varies from $1560-2020 \mathrm{~m}$ asl of these stations and local environment. Baramulla station due to its high altitude, more forest cover and rural vicinity has lesser evapotranspiration and thus lesser water requirement. Srinagar station on the other hand is located in urban area and has relatively less elevation than other stations. As such crop water requirement in this district is more than other districts.

The stage wise water requirement shows that during initial stage it was $69 \mathrm{~mm}$, during mid-season stage was 668 $\mathrm{mm}$ and during late-season stage was $175 \mathrm{~mm}$ in Kashmir Valley as a whole. The water requirement was maximum during the mid-season stage comprising nearly 73 per cent of the total water requirement, while it was minimum during initial stage comprising only about $8 \%$ of the total water requirement.

The monthly variation of average rainfall, $\mathrm{ET}_{0}$ and $\mathrm{ET}_{\mathrm{c}}$ for the entire Kashmir valley is shown in Fig. 1. During the initial stage rainfall is high and the crop is in dormant stage, thus irrigation is not required during this period. However in the mid-season stage rainfall is very low as compared to the crop evapotranspiration. Efficient irrigation planning and scheduling is thus necessary during this period. The water requirement decreased progressively during the late season stage up to the end of the crop season. This season experiences sufficient rainfall to meet the requirement of crop evapotranspiration.

\section{REFERENCES}

Allen, R.G., Pereira, L.S., Raes, D. and Smith, M., (1998). Crop evapotranspiration-Guidelines for computing crop water requirements-FAO Irrigation and drainage paper 56. FAO, Rome, 300(9), p.D05109.

Doorenbos J. and Pruitt W.O. (1977). Guidelines for predicting crop water requirements. Irrig. Drain Paper 24 (revised) Food and Agricultural Organization of the United Nations, Rome.

Kashyap, P.S. and Panda, R.K., (2001). Evaluation of evapotranspiration estimation methods and development of crop-coefficients for potato crop in a sub-humid region. Agril Water Mangmnt, 50(1), pp.9-25.

Ken A. Shackel, Terry L. Prichard, and Lawrence J. Schwankl Irrigation Scheduling and Tree Stress in Buchner, R.P. ed., (2012). Prune Prod Manual (Vol. 3507). UCANR Publications.

Mehta, R. and Pandey, V. (2015). Reference evapotranspiration (ETo) and crop water requirement (ETc) of wheat and maize in Gujarat. J. Agrometeorol., 17(1).107-113. 